\title{
Youth futures and a masculine development ethos in the regional story of Uttarakhand
}

\author{
Leah Koskimaki
}

\begin{abstract}
Research on the Uttarakhand region, which became a new state in 2000, has focused largely on agrarian livelihoods, religious rituals, development demands, ecological politics and the role of women in regional social movements. This essay discusses another dimension of the regional imaginary-that of a masculine development ethos. Based on ethnographic research and print media sources, this essay focuses on stories, politics, mobilities and imaginations of young men in the years immediately after the achievement of statehood. Despite increased outmigration of youth in search of employment, many young men expressed the dream of maintaining livelihoods in the familiar towns and rural spaces of Uttarakhand, describing their home region as a source of power and agency. In rallies and in print media, young (mostly upper caste) men expressed their disillusionment with the government and the promises of statehood, arguing that their aspirations for development and employment were left unfulfilled. Gendered stories of the region, told in Hindi in rallies and print media, contained references to local places, people and historical events and were produced through local connections and know-how, fostering a regional youth politics. The article argues that Uttarakhand as a region is shaped by the politics of local actors as well as embodied forms of aspiration, affiliation and mobility.
\end{abstract}

On a sunny and cool late winter's day in 2006, members of Uttarakhand's Organization of Unemployed Youth held a protest rally in Nainital, a popular Indian tourist destination and university town in the Himalayan foothills. ${ }^{1}$ Just over five years had passed since Uttarakhand had become a new state in the Indian union, and this group of young men had gathered outside the Collectorate situated above the town's Mall Road to protest the lack of local employment opportunities. 'My companions, why was our state made? (hamārā rājya kyom banā?) And after it was made, how come we were not granted our rights?', one nascent politician queried rhetorically, addressing the other young men present there. ${ }^{2}$ 'Today I want to tell the government that if this youth community (yuvā varg) can bring this administration into power, then it can also take it down!' The crowd clapped and cheered. 'We will have to fight', he exclaimed, 'because no person from Madras, Bengal or Bihar shall come for [jobs in] this state!' Another youth led the group in chants: 'N. D. Tiwari3 is a criminal! We won't stand for it!' These young men blamed the state government for unrealized promises of regional 'development', the main plank of the movement for a separate 
state in Uttarakhand. Their demands focused on the futures of local youth, many of whom had unsuccessful experiences with migration to urban centres outside the state for employment. Recently announced plans to set up factories and IT parks in the plains of the state, which would attract workers from other parts of India, renewed sentiments around a social and economic divide between the Uttarakhand hills and the plains areas. Creating more suitable employment opportunities within the mountain region and reserving jobs for locals, they argued, would help them to move out of the stage of youth and be able to fulfil their social and masculine responsibilities at home.

At this rally and other such political demonstrations that I attended in Uttarakhand post-statehood, local student union members often networked with other youth leaders who had travelled from neighbouring hill towns. They took turns giving speeches alongside politicians from a previous generation of youth who had been active in the movement for statehood in the 1990s. At such demonstrations, journalists from the local Hindi-language newspapers seemed to be always present, and youth leaders provided them with written political statements and a list of leaders' names to include in their coverage and publicity of these events in the next day's news. In all cases, I found that stories and slogans shared and recited at these rallies situated the region as the authentic setting for the imagination of youth futures. These young men described the hardships of out-migration in moral terms, where stories discuss life in the cities as causing many to 'go astray'. In contrast, they based their affection for their region, the Uttarakhand hills, not only on their attachment to the 'natural' clean and cool environment and landscape but also on their home as a source of power and familiarity. Their social and political lives hinged on regional travel and local connections and affiliations. As opposed to life in Delhi and other plain cities, travel within and between hill towns and rural areas was less convenient, yet such mobility helped youth to augment their local knowledge of how to 'get things done'-through their experience with the locality, news worlds, town bureaucracy and issues of rural 'underdevelopment'. Thus, the forging of regional relationships was key to navigating the future: as a student leader at a rally I attended in Ranikhet in 2006 explained, 'If a guy from among us studies and can get ahead, then he will think of us, he will know our pains and sorrows (dukh-dard). Only then will there be local development! (Tab yahām kā vikās hogā!)'

As this glimpse into regional youth politics reveals, in Uttarakhand, as in many states in India, development imaginaries and regional assertions are interlinked in the contemporary moment. And, as development aspirations are gendered as well as class and caste situated, regional identities can be better understood through grounded studies of the influences, interactions, social histories and mobilities of diverse actors (Koskimaki \& Upadhya, this issue). This essay explores one facet of such region-making-its generational and masculine development ethos. Similar to Paasi who urges us to attend to 'the significance of generation as a category which mediates between regions and individual life histories' (Paasi, 1991, p. 240), this article focuses on the circulation and politics of 'stories' among young men about their struggles and aspirations for Uttarakhand. This masculine development ethos is thus embedded in regional imaginaries, three aspects of which I 
discuss here: the development aspirations of young men; the moral orientations of future making, in which regional and caste affiliations play a prominent role; and the complexities of out-migration and regional travel. I discuss commonalities in the ways in which young men struggle to attain secure livelihoods, and thus address what has been termed the 'contemporary crisis of masculinity' in India (Chakraborty, 2014; Chowdhry, 2005; Jeffrey, 2010) through forms of regional assertion.

\section{A Masculine Development Ethos in the Making of a Region}

People who have called this largely rural and mountainous region home for several generations generally identify themselves as Pahari, or 'hill people', taken from the word pahār, meaning mountain. A long lineage of academic work has shown, directly or indirectly, the ways in which the Uttarakhand mountain region has been imagined and characterized, focusing largely on themes of its agrarian life, religious rituals, mountain landscape, development demands, social movements and local ecological politics. Linkenbach argues that 'nature in Uttarakhand, in its distinct and particular form, has become a major and explicit point of reference for the local population, both in their imaginaries of the future and development, and in their framework of identity construction' (2006, p. 152). As such, its mountain towns have been known for their spatial remoteness (see Mathur [2015] on Gopeshwar), and state-making in Uttarakhand has been shaped by agrarian subjectivities and practices (Galvin, 2014). The localized practices and politics of 'being Hindu' in Uttarakhand (Govindrajan, 2015) have also become part of the regional imaginary, where the mapping of pilgrimage sites (Pinkney, 2013) or the circulation of images of sacred shrines such as at Kedarnath (Whitmore, 2012) have played into the production of the region's image as 'The Land of the Gods'.

In fact, a Hindu nationalist presence has also influenced the politics of statehood based partly on the idea that it is a 'sacred geography' for Hindus (Tillin, 2013, p. 103), and Uttarakhand's regional landscapes and rivers have been politicized. The movement against Tehri dam, for example, brought together environmental activists and Hindu nationalists on common ground (Drew, 2017; Mawdsley, 2005; Sharma, 2009). The Chipko ândolan, or movement against the exploitation of its forests by 'outsiders', drew from a legacy of political protest around forest rights (Guha, 2000) and merged into the movement for a separate state. Chipko has been popularly framed as an ecofeminist movement (see Shiva \& Bandyopadhyay, 1986), a position that has been critiqued for not considering the role of men and students (Mawdsley, 1998). At the same time, women have played a large role in this and other social movements (Drew, 2014a). Gururani emphasizes a 'gendered geography of resistance' through which 'women signaled a modern regional identity that was consolidated in the terrain of a new political space' (2014, pp. 69-70).

Building on this work, this article discusses an insufficiently analyzed dimension of gendered regional assertion, that of youth masculinities. Considering the role of students in the region's social movements, and the relationship among youth outmigration, unemployment and demands for development in Uttarakhand, I discuss the aspirations and diverse political expressions of young men who voiced concern about development issues. As Paasi and 
Metzger argue, regions are constructed through the social and power relations of actors who 'assume key positions as activists and advocates in the process of articulating the meanings and functions attached to regions' (2017, p. 22). In this case, the story of the young man who struggles for his future and tries to find the 'proper way' overlaps with the story of Uttarakhand statehood.

Lack of desired salaries and opportunities for employment outside of the agricultural sector, combined with high aspirations of youth, has contributed to high rates of out-migration in Uttarakhand (Mamgain \& Reddy, 2016).4 Hanging out with members of the Akhil Bharatiya Vidyarthi Parishad (ABVP, a Hindu nationalist student organization) in Almora in 2006, a young man complained to me, It is said about Uttaranchal that the youth and the water of the mountains are not being used locally - instead they are flowing out for the use of outsiders. 5 And no one is here that can keep them in the state with employment, nor make use of the water to give us energy $(\bar{u} r j \bar{a})$. They need leadership that can avert them from going outside of the state.

A survey of editorials in local news media in both English and Hindi at the time of research also revealed this common lament about the problems of the state-a high level of youth outmigration and exploitation of local resources by 'outsiders'. Moller observed Kumauni villagers lament that 'the pahari people and land are being drained in favour of the plains: they feel economically disadvantaged, and complain that the government has not paid enough attention to developing the region for the local populace' (2000, p. 162). ${ }^{6}$ While some youth have succeeded in moving out for better schooling and more lucrative employment, young men without such cultural capital, language skills and backgrounds struggle to find work to support their families in the hills. Keeping such trends and sentiments in mind, here I focus on the lives, politics and aspirations of young men who either opted to remain in the region or returned after attempting to find secure employment in the plains. I discuss the political expressions of youth in various hill towns in the mid-range Himalayan belt, most with populations of around 30-40,000. I recorded their assertions and struggles during a period of ethnographic research after Uttarakhand became a new state, from 2005 to 2007, when youth in the region were barely beginning to connect on social media.

At the rally described above, a man who the participants referred to as their 'elder brother' made a speech voicing such sentiments. Waving his hand, he said encouragingly, 'Just as all people know, just as all youth know, the demand for Uttarakhand was to make men ( $\bar{a} d m \bar{\imath})$ self-sufficient and independent (ätmanirbhar). There was a purpose (maqsad) for it, that our men would find something, would gain something from it.' Such sentiments require an analysis of the predicament of youth in the regional context. Since 'youth' is not a homogeneous but rather a culturally constructed category (Bucholtz, 2002), the unemployment problem in Uttarakhand forced young men to endure a prolonged period of 'youth', as they could not take on new family roles or provide for the household in the hills and thus for the 'future' of the region on a larger level.7 As youth practices are oriented to this future, young men in Uttarakhand are expected to carry out family responsibilities. They 
tend to negotiate their futures within norms of a 'local hegemonic masculinity', 8 which is 'constructed in the arenas of face-to-face interaction of families, organizations and immediate communities' (Connell \& Messerschmidt, 2005, p. 849). In this essay, I show how young men use regional affiliation and expression to navigate these cultural politics in rallies, regarded as spaces where a 'masculine political agency has been central to the articulation of public politics' (Lukose, 2009, p. 154). I attend to the stories and politics of Hindu, mostly 'upper caste', youth who on one hand, are more likely to have some financial ability and social networks for such mobility (Mamgain, 2004, p. 18), yet are unable to find a way to move forward. Many young Brahmin or Rajput men struggle to fulfil regional caste-based norms of success and 'honour' (Anandhi, Jeyaram, \& Krishnan, 2002).9 I agree with Jeffrey's (2008) review of work on 'educated unemployed youth' that argues for a focus on the 'continued salience of politics in young men's lives' (p. 753) as well as their ability to 'construct new social networks' (p. 751), albeit in this case youth relied mostly on regional connectivity.

Youth aspirations in the region are, of course, diverse in form and expression; while some youth may have expressed boredom with the slow pace of life in hill towns or aspired towards urbanized lifestyles, most of those I met conveyed to me the desire to stay in familiar spaces, wrote poetry about their villages in local journals and magazines, or felt that their home world was a source of agency and power. Further, returning to the earlier discussion on Hindu nationalism and environmentalism, not all youth groups conform to a regional ecological idiom of protest: When I met Sunderlal Bahuguna at his residence near Tehri Dam in 2006, it was the nearby town's student union president who brought me there. The latter was also a member of ABVP, and a stern and vocal Hindu nationalist who invoked $g \bar{a} y$ and Gangā, and yet disagreed with Bahuguna's protest, citing the need for such development projects in the region.

Development aspirations in the region must also be situated in the context of the role of youth in the region's social and political history. While Kumaun and Garhwal were officially carved out as a separate administrative region of the mountainous north-western part of Uttar Pradesh to become India's 27th state in November 2000, political elites were already discussing the idea of Uttarakhand in the late colonial period (Guha, 2000; P. Kumar, 2000). During the nationalist movement, the circulation of stories and agendas through vernacular print media facilitated the development of a regional political vocabulary for youth that focused on notions of duty and sacrifice in the unique context of the mountains (Koskimaki, 2016). Development remained a political issue for young people in the 1970s, when members of youth organizations such as the Uttarakhand Sangharsh Vahini debated the question of regional development, arranged travel to villages to view and educate themselves on their conditions, set up committees for development programmes in rural areas (as reported in Yugwani, 1977) and were politically involved in the Chipko movement. The movement for statehood in the 1990 s was further motivated by student protests around the implementation of 'reservations' in Uttar Pradesh; the protests were especially sharp in this region because of the comparatively higher proportion of Brahmin 
and Rajput groups ${ }^{10}$ in the hill districts. They feared that the implementation of new reservations for 'OBCs' or 'Other Backward Classes' would encourage migration to the hills from the plains regions of Uttar Pradesh and thereby further reduce job opportunities for 'locals' in their hometowns (P. Kumar, 2000; Mawdsley, 1996, 1999; Moller, 2000). ${ }^{11}$

Regional assertion also grew out of demands for development and transparency in governance in a region often seen as 'backward' and 'neglected' in comparison with Uttar Pradesh and other 'plains' regions. ${ }^{12}$ Fiol emphasizes 'prevalent discourses-lack and loss-as a means of accounting for the experiences of cultural poverty in Uttarakhand, primarily in relation to neoliberal forms of capitalism' (2013, p. 85). Rangan notes that in the 1990s, student leaders from an earlier generation held rallies decrying the lack of development in the region: 'I found it intriguing that so many people in Garhwal were preoccupied with development, given that it was being subjected to a barrage of criticism elsewhere' (2000, p. 138). An analysis of the 2002 election results in Uttarakhand revealed that 'more than half of the population (nearly 57 per cent) considered development as the main election issue', and that 'the younger generation' was more concerned about development than the older generation (S. Kumar, 2002, p. 1882). My discussion of development here builds upon recent work that has studied development aspirations within their regional and historical contexts, focusing on agency, politics, social movements or livelihoods. ${ }^{13}$ In Uttarakhand, references to 'development' or vikās ${ }^{14}$ meant a general notion of progress, improved infrastructure in the mountain environment, amenities and improved livelihoods, and for conflicted young men, access to employment and the ability to fulfil duties to family and home. As Pandian has argued, 'desires for development' are 'propelled by many different visions of advancement-material, spiritual, familial, social-that are not always easily reconcilable' (2008, p. 223). I similarly situate 'development' in the context of regional aspirations and subjectivities. Politicians from the region, youth or otherwise, selectively link political discourses around natural landmarks, such as regional mountains and rivers, to draw people into development-related agendas (Koskimaki, 2011). As a youth leader at a rally I attended in 2007 claimed, 'The meaning of Uttarakhand comes from the pahār $\square$ (mountain), and according to our physical circumstances, we have been backward people. We were not getting any jobs...The state of Uttarakhand was made to get that employment, for local development!'

\section{Regional Stories and Masculine Futures}

Youthful ideals for the future shape the content and circulation of stories of struggle, corruption, brotherhood, migration and home and thus contribute to the production of a regional imaginary. I borrow from de Certeau's description of stories as 'spatial trajectories' and 'spatial practices' which 'traverse and organize places' (de Certeau, 1988, p. 115) and serve to connect ideas; their 'polyvalent' quality, he writes, 'gives them functions that change according to the groups in which they circulate' (1988, p. 125). In masculine youth publics, such 'stories'-the affective expression of the experiences of oneself or others-are part of region-making practices. Sivaramakrishnan and Agrawal also refer to the importance of storytelling, pointing to a 'micropolitics' that cannot be accurately described 
through the commonly used concepts of 'discourse' or 'narrative', which imply either strategies of power or over-emphasize 'structure and linearity' (Sivaramakrishnan \& Agrawal, 2003, p. 49). It is through an emphasis on stories, the authors suggest, that we can return agency to the subject of development, as stories 'return us relentlessly to the moments of production, to a wide cast of authors, editors, publicists and critics' (Sivaramakrishnan \& Agrawal, 2003, p. 49). Furthermore, stories are part of a lineage of experience and locality: as Walter Benjamin argued in 1936, although the art of storytelling and the value of experience are fading, storytelling is 'an artisanal form of communication' (Benjamin, 2006, p. 149) in which memory and counsel are passed from generation to generation. Consequently, stories occupy an important space in regional publics, connecting people through both political networks and social imaginaries.

Stories as 'spatial practices' also culturally produce the newly imagined region wherein development becomes an index of the future. During my research in Uttarakhand's hill towns, I recorded a myriad of stories told in rallies, in conversation at tea stalls and in student organization meetings and heard while hanging around with students at universities. Print media such as local newspapers, pamphlets, student yearbooks and magazines, also conveyed a politics of development as seen through the struggles and fears of young men. Stories, in their telling, draw private aspirations out into public space and thus shape ideas of hope and the 'progress' of the 'region', which hinge on 'collective' developed futures.

Explicit references to the names of towns, the traditions of travel between them for political networking, and their unique character shaped everyday politics for young men. Below I discuss ways that this masculine development ethos has been evoked in political scenes.

At a rally in Ranikhet in 2006, members of the local student union, activists from the earlier movement for statehood, members of an unemployed youth organization and local veterans gathered right off the main market thoroughfare. A 'senior' leader who had been active in the statehood movement in the 1990s spoke, explaining that although he and his companions had been out of college for 10 years or so, they still travelled 'place to place' and continued 'to see jobless youth roaming around'. He implored,

In every house there are four or fi brothers or sisters, the father is retired, the sister's wedding is pending, and the boy is unemployed. At home the family curses and insults him, and when he goes out he gets pushed around, so where will the unemployed youth go?

Denying any political party affiliation, they discussed the meaning of development for young men via a discourse of rights and self-worth:

The government has become incapable of generating employment. Today our brother, who thought he had attained self-worth after the making of Uttarakhand, is going astray...Today if computer jobs or other significant jobs become available, people come from 
Delhi, Ghaziabad, Meerut or other big cities to do them. Why do they intrude into Uttarakhand? If there were employment here, then the men of Uttarakhand would do it! If there was any job at all here, an Uttarakhandi would do it!

Much of the youth protest during the period after the achievement of statehood was oriented around criticisms of the development policies of N.D. Tiwari, then Uttarakhand's Congress Party Chief Minister. Tiwari had anointed himself as Vikas Purush (the 'Man of Development' or 'Progressive Man') and had affiliated himself with the State Infrastructure and Industrial Development Corporation of Uttaranchal Limited (SIDCUL), an organization of banks set up to facilitate the establishment of industrial areas in the plains districts of Uttarakhand, as well as an IT park in Dehradun, an industrial estate called a 'Growth Centre' in Kotdwar and a 'Biotechnology Park' in Pantnagar. Youth politicians in the hills decried the role of SIDCUL in promoting the influx of 'outsiders' into the state, who they claimed would be taking up many of the new jobs generated from this kind of development, and demanded that the government create employment quotas and better loan policies for regional youth. According to the youth I met, N.D. Tiwari was luring investment into the plains areas and hence reinforcing the pattern of relative underdevelopment in the mountain areas, leading to feelings of neglect and the pattern of outmigration. They also demanded that locally suitable industries should be developed in the mountain areas, such as the marketing of herbs or bettering the infrastructure to promote tourism. 15 These critiques came from groups across the political spectrum: one left-leaning organization, Parivartankāmi Chātr Sanghathan (PKCS, or Students for Change) circulated a pamphlet in Hindi on SIDCUL that presented statistics to show that SIDCUL's policies would not help enough local youth to gain employment. It criticized N.D. Tiwari for 'giving concessions to industrialists' by allowing them to merely 'take advantage of provisions':

The Vikas Purush is so clever that on the one hand he has become the well-wisher of the wealthy capitalists, and on the other hand he is patting himself on the back for the very little job opportunities that have come out of these industries. He is very successfully acting as the well-wisher of the unemployed. This illusion is being performed through the State Industrial Development Corporation Limited (SIDCUL).

Interestingly, this pamphlet also criticized what it termed the "political uproar to provide 75 per cent reservation to the natives of Uttaranchal', blaming 'corrupt politicians' for dividing 'the public' and taking advantage of sentiments against 'outsiders'. However, a leader of the Organization for Unemployed Youth argued that 'the government is setting up factories with our money, getting subsidies but not giving us any employment'. Their anger about SIDCUL's plans also stemmed from the fact, as discussed in this article's introduction, that many local youth continued to struggle to find work that suited their cultural, educational, caste and familial 'status'. This status hinged on local ideals of masculinity that revolved around the idea of respect and local forms of sociality and affiliation. At a rally in Nainital, a youth leader complained, 'So many big companies are coming into Uttaranchal, but they are bringing their own people along with them.' Demanding that jobs needed to be reserved for local youth, he argued, 'For how long can we be baggage for our family, for how long can our family members continue to feed and look after us?' This sentiment regarding gendered labour 
roles was most strongly elaborated by Hindu nationalist youth with whom I interacted; in a conversation with young ABVP members in Almora, one young man asserted, 'To run a home, two people are necessary. One must earn (kamāna) the livelihood and the other to cook food and care for the household. This is our family system (vyavasthā).'

Youth futures were explicitly linked to regional connectivity: during a demonstration in Ranikhet, a man who had been a student leader during the movement for statehood, directing his remarks towards some businessmen in the crowd, referred to regional economic and social life as a 'circuit', using the English term:

If Uttarakhand's unemployed boys get employment, whether it be a government job or nongovernmental, they will get a monthly salary and come home with that salary. So from where will he buy clothes, from where will he buy food? From your store...When he has money in his pocket, you will benefit. All these things depend on the economy, and everything is bound together in a circuit. Brothers, this circuit will work properly (sirkat sahī chalegā), this Uttarakhand will work properly, but if it is interrupted, then everyone's condition deteriorates.

The sentiments expressed in this rally were part of a popular discourse on development in the region. In fact, the feelings articulated in these speeches could also be read about in the newspapers and magazines in the region. Many of the same lines were repeated to me in interviews with students, young journalists and activists, and youth leaders from other hill towns in the state.

The Uttarakhandi young men I met responded to this apparent crisis of masculinity through a politics of regional assertion and moral obligation, which often in turn reflected certain narratives of caste identity. For example, a student leader in Nainital related a story to me about a professor who had tried to bribe him in exchange for his silence about the sexual harassment of female students: 'You can't buy us. We are not that type of people. I'm a Rajput. Well, I don't believe in this caste system, but as a Rajput, I have some moral character.' In such 'poetics of manhood', Herzfeld (1985, p. 11) argues, notions of 'self-regard (eghoismos)' work 'on behalf of a collectivity-be it kin group, patriline, village, region, island, or county' and thus resonate in local contexts. Satendra Kumar has also shown how youth politics in provincial Uttar Pradesh often works through 'biradari' (here 'caste', but the term also refers to 'brotherhood', family ties or other affiliations) where 'relationships of mutuality and reciprocity between student leaders and students are generated and cultivated in the language and world of caste, kinship and territory that are embedded in the local moral and political cosmologies' (2012, p. 58). These are some of the ways in which the region is socially and politically constructed.

\section{Returning to the Region}

Contrary to popular assumptions that Indian youth aspire only to be globally mobile, many young men in Uttarakhand expressed instead the desire for 'regional mobility', to remain where one's affiliations, familial networks, friends and understandings of gestures 
and language reside. These sentiments had two facets: first, the issue of outmigration and the problems that have arisen from it, leading to demands for development at home; and second, the role of mobility within the region as a source of struggle but also knowledge, connectivity and power. As discussed above, young men's experiences of migration to the cities for employment, and the hardships that they faced there, entered the political scene and thus fed new kinds of regional assertion. Consequently, knowledge of the region, its villages, struggles and how to navigate everyday life in the hill towns were prerequisites for success in social and economic spheres as well as for becoming local political leaders. Youth leaders who travel to attend rallies in other towns engaged in 'meetingness' and 'copresent interaction' which are 'face to face' and 'embodied' (Urry, 2003, pp. 156, 165) in their networking and forging of friendships. In this section, I offer a few examples of the way stories about migration and sentiments regarding travel within the region have entered regional youth politics.

In Uttarakhand, mobility has played a role the region's changing representation: most prominently, Joshi (2015) argues that 'drivery' in Uttarakhand-access to new kinds of mobility for unemployed young men such as taxi driving-has allowed for new kinds of 'socio-spatial transformations' leading to 'new horizons'. She argues that travel plays a large role in shaping a 'sense of identity', where 'mobility is critically constitutive of the (re)imagination of people and places' (p. 17). Because it is mostly men who migrate out, one needs to consider region making in the context 'gendered mobilities' of 'movement, meaning, practice and potential' (Cresswell \& Uteng, 2008, p. 2) for a majority population of youth who are 'restless and rootless' (Pant, 2012). Men rely on what Cresswell terms 'constellations of mobility', defined as 'historically and geographically specific formations of movements, narratives about mobility and mobile practices'(Cresswell, 2010, p. 17). Regional mobility is shaped by social relations, religious identities, practices of work, kinship, marriage and differential access to urban spaces (see also Verstappen, 2016, and this issue). As young men move between hill towns, to rural areas, and outside the region, these experiences shape their politics. Scholars such as Amin (2004, p. 34) have argued that regions 'are made through the spatiality of flow, juxtaposition, porosity and relational connectivity'; In this way, mobility complicates Uttarakhand's enduring representation as 'bounded' by landscape and history, as new generations remake meaning through forging new connections.

Due to the lack of opportunities within the region, many men migrate to India's cities, only to find the struggles, environment and expectations too difficult. During my time in Uttarakhand, I heard many stories about the difficulty of trying to earn a livelihood in the plains, which have furthered the feeling of division in the hills. Stories that youth shared with me and with one another paint a picture of a harsh and lonely life in the cities, where friends disappear, illness takes over, and migrants 'lose their way' by dabbling in drugs, alcohol, or other 'negative' behaviours. While politically youth discuss the lack of opportunity in the villages-as one political science student and youth leader from Ranikhet exclaimed at a rally, 'You must have seen in our state how many villages have been emptied of their youth, and how they are escaping to the plains'-many young men do stay in the hill towns or rural areas 
seeking opportunities at home. A young Rajput man told me he left his home outside the town of Almora because his uncles 'took' the portion of family land that he felt belonged to him. He then was exploited by the management of a pizza restaurant in Mumbai and returned to Uttarakhand to find a job inspecting the distribution of cigarettes at shops in neighbouring towns on his motorcycle. Not a great job, but at least he was home, he said. Another man told me about his friend who disappeared in the city-no one had heard from him after he left the hills. They complained about the suffocating heat and living conditions, and how their health suffered as they often contracted jaundice and other ailments due to what they felt was the poor quality of water and food in the cities. Of course, not all experiences were negative, but these stories were meaningful for youth who decided to remain and 'do something for their village' or for their 'own region', and further, such stories were also evidence to the struggles of migration used by youth leaders in their speeches.

Vernacular print media produced by youth activists also highlighted the themes of home and migration. In a flyer put out by the left-leaning PSF (Progressive Students Forum) titled 'Javām Qadm' (Youth Steps), ${ }^{16}$ a student from Almora's university campus published a reflective piece in Hindi on outmigration titled, 'Youth are Compelled to Flee the Mountains'. The essay reveals how a development ethos becomes linked with affective regional attachments to home-articulated as a part of a rural imagination. It blames the government and local industries-which are connected by economic benefits from 'development' that accrue to the political class-for exploiting Uttarakhand's natural resources. Part of this argument comes from a long struggle in the hills over forest rights (see Guha, 2000; Pathak, 1997; Rawat, 1999). In this exploitative relationship, he writes, 'they have prohibited the people to visit the forest for their basic needs, which is their fundamental right. Due to this, the villages are regularly lagging behind.' The author blames lack of development for the struggles of the region's youth: 'In such a situation, local youth consider travelling out to earn money and make their future. Because of this, the youth flees to Delhi and other places'. Despite earning very little for hard work, the 'hill youth gets stuck in a cycle' in which he struggles to fulfil his social responsibility, yet longs for the natural beauty of his homeland:

Even then he works very hard and somehow fills his stomach. When he remembers his home, he remembers the ponds and rivers (gār-gadhere-naule), cows, goats and cow herders ( $g \bar{a} y$-bakriyām-gvāle) and the milk, curd and whey (dūdh-dahī-chānch) - then his heart weeps. But in the longing of one day returning to his home with lots of money, he again starts working with more enthusiasm. His parents wait for his letters at home, but how could he send a letter? Because at home his parents are aging and his grown-up sister is to be married, but his salary is just 1200 rupees. When he becomes very worried then a thought appears in his mind that by doing farming for his livelihood, he can spend his life in his own village....and he returns to his village. He works very hard, but without rains, how will there be any crops? When whatever is produced is ruined by pigs and monkeys? In such a situation, what should the youth do? Would he commit theft or robbery?...Or could he visit Delhi again for the 1200 Rupees?...Or fight for changing those cruel laws that are compelling him to move here and there and ruin his dreams under his feet? 
He concludes that the 'revolutionary student (krāntikāri chātr)' should go to villages and 'merge him or herself with the struggling people of that place...Today the country (deś) needs such kind of students-youth with understanding and dedication'. Such pamphlets convey a political ideology, with a poetics of locality and future-making. Regional knowledge was often expressed as something that one had to continually gain and perform as a moral duty and part of self-fashioning. Travel to the village was a way of knowing one's region, at times even affirming it as a 'real' and 'authentic' part of Uttarakhand.

In this way, young people often expressed the need to visit (or show me) less travelled areas in the state. A young activist and journalist for a regional political newspaper once asserted to me that his work 'demands lot of travelling and movement because we need to know about people, places and the problems of the villages'. He was proud that he knew more about rural development woes than bureaucrats, ministers and administrative officers, and often travelled to places where 'jeeps cannot go'. In fact, at many rallies, a common complaint was the

way corrupt and disinterested politicians moved around. They spoke about the helicopter issue'-senior politicians were known to come in and out of small towns or villages with ease by travelling above the ground by helicopter, therefore, not really seeing (or being inconvenienced by) the poor condition of the roads or the neglected countryside. At one rally, a seasoned 'youth' leader implored:

I want to ask Chief Minister Tiwariji...Can't his helicopter come to Ranikhet, can't his helicopter come to Tehri or Darchula? No, it can't go! He has confined Uttarakhand to only four [plains] districts. He is looking at Uttarakhand today only through those four districts. But the definition of Uttarakhand is 'mountain'.

Young activists also were adamant that a developed Uttarakhand required intimate knowledge of the region that comes with travel through its towns and villages, especially those that are 'remote', as such journeys, whether to one's ancestral home, or for political campaigning or journalistic purposes, were also away of orienting oneself: members of PSF, and left-wing student group, organized gamv calo abhiyān or 'campaigns' to travel to nearby villages to educate themselves on the problems of under-development and neglect while bringing 'progressive' ideas to the rural areas in traditions of activism.

Finally, notions of time were also discussed in relation to the issue of travel. The poor quality of roads and lack of 'facilities' in villages led youth to talk about time in terms of distances. Many college students had to rent rooms in the town to pursue their studies because travel from their village to college took too long. In Srinagar, Garhwal, a student leader conveyed to me, 'All the students live here on rent. In places like Delhi and Mumbai, the students travel distances up to even a hundred kilometres, but they feel no difficulty because there are many facilities. There are buses, there are trains, everything is there.' However, they claimed that in the hill town, travel was not only costlier but took too much 
time: 'It takes one and half hours for one way to travel. Nobody is that crazy that he will go up and down [the hills] every day.'

As development was a major motivation behind the protests and aspirations for statehood, expectations for progress have become linked with other social forms and negotiations over power. A focus on youth and generational differences is of interest in this context, as employment and education issues were part of youth aspirations and struggles. For this reason, mobility created an underlying urgency to the discourses of development in the making of this hill region.

\section{Conclusion}

This article has taken an anthropological and ethnographic approach to understanding the production of regional Uttarakhand, moving beyond economic, linguistic or macro-level political analyses by arguing that regions are also shaped by the mobility and politics of various actors and the formation of solidarities. Specifically, it shows how the development aspirations of young men have contributed to the cultural mapping of the region. While much of the academic and popular literature on Uttarakhand has focused on its struggle for autonomy, few scholars have analyzed the ways in which a complex gendered politics of ambition and affiliation contribute to the production of a regional imaginary.

The stories young men share show concern with how a 'lack' of development kept them from moving on to the next stage of life, where adulthood is culturally determined by employment status, marriage and family. Regional actors hold varying positions in this imaginary; the men in this regional story of Uttarakhand wield power through their caste affiliations, friendships and local knowledge. Such regional affinities also involve a sort of regional return, where one has to prove their local 'embeddedness' (Verstappen, this issue) and experience. Still, while the youth I met came from various political affiliations and backgrounds, they were united in fighting to leave an imprint on regional futures. Youthful approaches to politics and development worked on many different levels, of media, meetings and affect, and these interconnected processes created intimacy through stories. Rallies, both small and intimate or large and well performed, 'produce a common terrain of aspiration' and drew various actors into a 'common performative space' (Appadurai, 2004, p. 78). Discussions about their ability to travel to difficult places, the compulsions of out-migration and simultaneous attachment to home, knowledge of rural life and experience with the struggle of Uttarakhand, all figure in the way the region is 'made' and 'known'.

What I have not discussed at length in this article is what opportunities are available at home, which often come with the regional knowledge, traditions or qualifications of local youth. Thus, many young men tried to succeed in other ways by joining 'traditional' local professions such as the Indian army. Some young men aligned themselves with regional issues and politics by joining local NGOs, journalism or youth organizations, acting on their desire to engage in 'social service' and 'do something for their village'. Intellectual 
youth studied regional histories and ecological issues at universities in the main towns of Nainital, Almora or Srinagar, and then often became teachers in colleges in the more 'remote' areas in the state, while others worked to join 'politics as a vocation'. Some became involved in local businesses or contract work in construction projects. Overall, most of these avenues required regional connections, familiarity and affiliations as well as movement throughout the region.

Habermas describes 'lifeworld contexts of relevance' where the immediate surroundings constitute the world that is 'within my actual reach' and the 'region, the country, the continent and so on, constitute, as regards space, a "world within my potential reach" (1987, p. 122). In Uttarakhand, young men's lifeworlds grasp at the world within their actual reach and the knowledge that circulates within these imagined borders. Yet the dream of mobility and 'potential reach' is one of both disappointment and ambition. While various work on the figure of 'youth' in India has interestingly characterized them as 'consumer citizens' (Lukose, 2009) and savvy cosmopolitans in an era of globalization, or as 'fixers' engaged in political career making (Jeffrey, 2010), the case described here instead highlights the retreat from such fast-paced mobilities back into a regional fold-where politics is a way of navigating the struggles of life in a region labelled for so long as 'backward'. When confronted with stories of struggle, such spatial practices remind us that the region is made and produced through intimate interactions and aspirations and cannot be easily explained through mere descriptions of cultural or economic territories.

\section{Notes}

1. The funding for this research was provided by a Fulbright-Hays Doctoral Dissertation Abroad (DDRA) grant and a University of Washington Chester Fritz Grant for International Exchanges. The author thanks Carol Upadhya for her insightful feedback on multiple drafts of this article, and Sanjeev Routray, Vegard Iversen and an anonymous reviewer for their helpful comments. K. Sivaramakrishnan and Sasha Welland offered valuable suggestions on these ideas in their earlier stages. All errors and omissions are the author's own.

2. While most regional youth spoke Kumaoni or Garhwali at home, they mixed their mother tongue with Hindi in conversation with each other in public places, and most used a more 'standardized' Hindi in their speeches and print expression, and in conversation with the author. All rallies and conversation cited in this paper were conducted in Hindi and translated by the author. The stories from print media were translated by $\mathrm{Mr}$ Naim Siddiqui in collaboration with the author.

3. Narayan Dutt Tiwari, of the Congress Party, was Uttarakhand's Chief Minister at the time, serving from 2002 to 2007.

4. Mamgain has summarized the statistical data to show that 'there has been an absolute decline in the number of main workers in the state (from 2.16 million to 1.97 million) during 1991 to 2001 ' (2007, p. 6).

5. A common idiom in the region goes, 'Neither the youth nor the waters belong to the hills' (Pahār kā pānī aur pahār kī javānī, donom pahār ke liye nahīm haim) (P. Kumar, 2000, p. 83). 
6. For a discussion of various perceptions of the division between the plains and the hills, see Moller (2000) who notes, based on her research in a Kumauni village, that 'the claim to moral superiority over plains people, is central to Kumaonis' definition and construction of plains people as "outsiders"' (2000, p. 157). While I would not use the term 'superiority' in this context, the general feeling of moral upright living in the mountains contrasted and grew out of negative experiences in the plains, which were perceived as exploiting the region and its resources.

7. On this phenomenon, also see Durham (2000), Mains (2007), McDowell (2003), Osella and Osella (2006) and Jeffrey, Jeffery and Jeffery (2008).

8. The now much-amended notion of 'hegemonic masculinity' was termed by Carrigan, Connell and Lee (1985) to discuss socially normative gender roles, and unrealistic yet influential characterizations of manhood, with a focus on sexuality. Jeffery, Jeffrey and Jeffrey have critiqued the concept, for example, arguing that young men do not merely absorb the dominant accounts circulated in development, media and other discourses, pointing rather to the 'improvised and irreverent nature of their performances' (2010, pp. 74-75).

9. Here I do not assume a uniform masculine response to social responsibility and gendered expectations. As Osella and Osella rightly argue, 'Men may cultivate a façade of normativity while privately acting in unsanctioned ways' (2006, p. 19).

10. Gururani argues, 'On the one hand, the mobilization was certainly casteist, but at the same time, it was not directed against the lower castes. Given the demographic profile of the region as outlined above, most of the participants in the rallies were upper caste but at this phase, the movement was neither against the Dalit nor was it a clearly articulated demand for separate statehood...Both Dalit families and upper caste families saw reservation for OBCs as a threat to jobs for their sons, enabling a shift from a politics of caste (upper against lower) to a politics of region (mountain against plains)' (2014, p. 74).

11. Mawdsley points out that at the time of her writing, 82 per cent of the population of the hill districts was rural, and highlights the 'widely accepted estimate (based on the 1931 Census)' of the caste break-up of the population as 74 per cent 'upper caste' and around 2 per cent OBCs in the region, in contrast with a 17 per cent upper caste population in Uttar Pradesh (Mawdsley, 1999, p. 103). While these figures cannot be confirmed as the Census of India has not collected caste-wise data since 1931 (apart from SC/ST), my fieldwork revealed that Brahmin and Rajput Hindu groups tend to dominate in the region's politics and administrative arenas.

12. The relationship between development, 'backwardness' and the politics of statehood has been elaborated by various scholars, including Fiol (2008), Mawdsley (1998), P. Kumar (2000), Moller (2000), Rangan (1996, 2000) and Tillin (2013).

13. See, for example, Asher (2009), Drew (2014b), Klenk (2003), Rangan (1996) and Sivaramakrishnan and Agarwal (2003). These build on earlier work within the anthropology of development that emphasized 'questions of subjectivity, knowledge, and power' (Escobar, 1988, p. 438), and that employed post-structural and Foucauldian approaches to show the ways in which discourses of 'underdevelopment' and the 'Third World' constructed development as a governing apparatus (e.g., Escobar, 1984; Esteva, 1992).

14. Similarly, Pigg discusses the localized idiom of 'bikas', or development, in Nepal in 'the orienting of individuals in a social space' (1992, p. 499). 
15. As one youth leader exclaimed in a rally in Ranikhet, "When the development of Munsiyari, Darchula, Badrinath, Pindari, and Kedarnath takes place, the tourists will come. And they will go along the road through Ranikhet, the road through Almora, the road through Garampani, and through Dwarahat, and will stay there.'

16. Javām, judging by the way it is spelled on the flyer, literally means 'soldier' or 'warrior', and in other contexts means 'manly' and 'courageous'. However, I am defining this term here as 'youth', which is its secondary meaning, and its meaning when spelled as javān (McGregor, 1993, p. 363). 


\section{References}

Amin, A. (2004). Regions unbound: Towards a new politics of place. Geografiska Annaler. Series B, Human Geography, 86(1), 33-44.

Anandhi, S., Jeyaranjan, J., \& Krishnan, R. (2002). Work, caste and competing masculinities: Notes from a Tamil village. Economic and Political Weekly, 37(43), 4397-4406.

Appadurai, A. (2004). The capacity to aspire: Culture and the terms of recognition. In V. Rao and M. Walton (Eds), Culture and public action (pp. 59-84). Stanford: Stanford University Press.

Asher, K. (2009). Black and green: Afro-Colombians, development, and nature in the pacific lowlands. Durham: Duke University Press.

Benjamin, W. (2006). The storyteller: Observations of the works of Nikolai Leskov. In H. Eiland and M.W. Jennings (Eds), Walter Benjamin: Selected writings, 1935-1938 (Vol. 3, pp. 143-166). Cambridge, MA and London: Belknap.

Bucholtz, M. (2002). Youth and cultural practice. Annual Review of Anthropology, 31(1), $525-552$.

Carrigan, T., Connell, B., \& Lee, J. (1985). Toward a new sociology of masculinity. Theory and Society, 14(5), 551-604.

Certeau, M.D. (1988). The practice of everyday life (trans. S. Rendall). Berkeley: University of California Press.

Chakraborty, C. (2014). Mapping South Asian masculinities: Men and political crises. South Asian History and Culture, 5(4), 411-420.

Chowdhry, P. (2005). Crisis of masculinity in Haryana: The unmarried, the unemployed and the aged. Economic and Political Weekly, 4O(49), 5189-5198.

Connell, R.W., \& Messerschmidt, J.W. (2005). Hegemonic masculinity: Rethinking the concept. Gender and Society, 19(6), 829-859.

Cresswell, T. (2010). Towards a politics of mobility. Environment and Planning D: Society and Space, 28(1), 17-31.

Cresswell, T., \& Uteng, T.P. (2008). Gendered mobilities: Towards a holistic understanding. In T. P. Uteng and T. Cresswell (Eds), Gendered mobilities (pp. 1-12). Burlington: Ashgate.

Drew, G. (2014a). Mountain women, dams, and the gendered dimensions of environmental protest in the Garhwal Himalaya. Mountain Research and Development, 34(3), 235242.

---. (2014b). Developing the Himalaya: Development as if livelihoods mattered. Himalaya, the Journal of the Association for Nepal and Himalayan Studies, 34(2), 7.

---. (2017). River dialogues: Hindu faith and the political ecology of dams on the sacred Ganga. Tuscon: University of Arizona Press.

Durham, D. (2000). Youth and the social imagination in Africa: Introduction to parts 1 and 2. Anthropological Quarterly, 73(3), 113-120.

Escobar, A. (1984). Discourse and power in development: Michel Foucault and the relevance of his work to the Third World. Alternatives, 10(3), 377-400.

--- (1988). Power and visibility: Development and the invention and management of the third world. Cultural Anthropology, 3(4), 428-443.

Esteva, G. (1992). Development. In W. Sachs (Ed.), The development dictionary: A guide to knowledge as power (pp. 6-25). New York: Zed Books. 
Fiol, S. (2008). Constructing regionalism: Discourses of spirituality and cultural poverty in the popular music of Uttarakhand, North India (PhD dissertation). University of Illinois at Urbana-Champaign.

--- (2013). Of lack and loss: Assessing cultural and musical poverty in Uttarakhand. Yearbook for Traditional Music, 45, 83-96.

Galvin, S.S. (2014). Organic designs and agrarian practice in Uttarakhand, India. Culture, Agriculture, Food and Environment, 36(2), 118-128.

Govindrajan, R. (2015). How to be Hindu in the Himalayas: Conflicts over animal sacrifice in Uttarakhand. In M. Rangarajan and K. Sivaramakrishnan (Eds), Shifting ground: People, animals, and mobility in India's environmental history (pp. 1-27). New Delhi: Oxford University Press Scholarship Online.

Guha, R. (2000). The unquiet woods: Ecological change and peasant resistance in the Himalaya. Berkeley: University of California Press.

Gururani, S. (2014). Geographies that make resistance: Remapping the politics of gender and place in Uttarakhand, India. Himalaya, the Journal of the Association for Nepal and Himalayan Studies, 34(1), 12, 66-79.

Habermas, J. (1987). The theory of communicative action: The critique of functionalist reason (Vol. 2) (trans. T. McCarthy). Boston, MA: Beacon Press.

Herzfeld, M. (1985). The poetics of manhood: Contest and identity in a Cretan mountain village. Princeton: Princeton University Press.

Jeffrey, C. (2008). 'Generation nowhere': Rethinking youth through the lens of unemployed young men. Progress in Human Geography, 32(6) 739-758.

---. (2010). Timepass: Youth, class, and the politics of waiting in India. Stanford: Stanford University Press.

Jeffrey, C., Jeffery, P., \& Jeffery, R. (2008). Degrees without freedom? Education, masculinities, and unemployment in North India. Stanford: Stanford University Press. Joshi, B. (2015). Memes of mobility and socio-spatial transformation: 'Drivery' in Uttarakhand. Economic and Political Weekly, 5o(1), 17-21.

Klenk, R. (2003). 'Difficult work': Becoming developed. In K. Sivaramakrishnan and A. Agrawal (Eds), Regional modernities: The cultural politics of development in India (pp. 99-121). New Delhi: Oxford University Press.

Koskimaki, L. (2011). Youth publics and embodied politics: Genealogies of development aspiration in North Indian hill towns (PhD thesis). University of Washington.

Koskimaki, L.M. (2016). Addressing the youth: Emerging youth publics in late colonial Uttarakhand. Himalaya, the Journal of the Association for Nepal and Himalayan Studies, 35(2), 41-55.

Kumar, P. (2000). The Uttarakhand movement: Construction of a regional identity. New Delhi: Kanishka Publishers.

Kumar, S. (2002). Assembly elections: Marginal difference. Economic and Political Weekly, 37(20), 1879-1882.

Kumar, S. (2012). Ethnography of youth politics: Leaders, brokers and morality in a provincial university in Western Uttar Pradesh. History and Sociology of South Asia, 6(1), 41-70. 
Linkenbach, A. (2006). Nature and politics: The case of Uttarakhand, North India. In G. Cederlof and K. Sivaramakrishnan (Eds), Ecological nationalisms: Nature, livelihoods, and identities in South Asia (pp. 151-169). Seattle, WA: University of Washington Press.

Lukose, R.A. (2009). Liberalization's children: Gender, youth, and consumer citizenship in globalizing India. Durham: Duke University Press.

Mains, D. (2007). Neoliberal times: Progress, boredom, and shame among young men in urban Ethiopia. American Ethnologist, 34(4), 659-673.

Mamgain, R.P. (2004). Employment, migration and livelihoods in the hill economy of Uttaranchal (PhD dissertation). Jawaharlal Nehru University.

---. (2007). Growth, poverty, and employment in Uttarakhand (Working Paper No. 39, pp. 1-15). New Delhi: Institute for Human Development.

Mamgain, R.P., \& Reddy, D.N. (2016). Out-migration from the hill region of Uttarakhand: Magnitude, challenges and policy options (Working Paper No. 218). Lucknow: Giri Institute of Development Studies. Retrieved 25 April 2017, from http://www.gids.org. in/DownloadMaterials/WP\%20218.pdf

Mathur, N. (2015). A 'remote' town in the Indian Himalaya. Modern Asian Studies, 49(2), 365-392.

Mawdsley, E. (1996). Uttarakhand agitation and other backward classes. Economic and Political Weekly, 31(4), 205-210.

- - . (1998). After Chipko: From environment to region in Uttaranchal. The Journal of Peasant Studies, 25(4), 36-54.

---. (1999). A new Himalayan state in India: Popular perceptions of regionalism, politics, and development. Mountain Research and Development, 19(2), 101-112.

- - . (2005). The abuse of religion and ecology: The Vishwa Hindu Parishad and Tehri Dam. Worldviews: Global Religions, Culture, and Ecology, 9(1), 1-24.

McDowell, L. (2003). Redundant masculinities? Employment change and white working class youth. Malden and Oxford: Blackwell Publishing.

McGregor, R.S. (1993). The Oxford Hindi-English dictionary. New York: Oxford University Press.

Moller, J. (2000). Anti-reservation protests and the Uttarakhand pro-autonomy movement: Caste and regional identities in the Indian Himalayas. South Asia Research, 2O(2), 147-169.

Osella, C., \& Osella, F. (2006). Men and masculinities in South India. London and New York: Anthem Press.

Paasi, A. (1991). Deconstructing regions: Notes on the scales of spatial life. Environment and Planning A, 23(2), 239-256.

Paasi, A., \& Metzger, J. (2017). Foregrounding the region. Regional Studies, 51(1), 19-30.

Pandian, A. (2008). Devoted to development: Moral progress, ethical work, and divine favor in South India. Anthropological Theory, 8(2), 159-179.

Pant, P. (2012). Dream turning into a nightmare in Uttarakhand. Economic and Political Weekly, 47(14), 18-21. 
Pathak, S. (1997). State, society and natural resources in Himalaya: Dynamics of change in colonial and post-colonial Uttarakhand. Economic and Political Weekly, 32(17), 908-912.

Pigg, S.L. (1992). Inventing social categories through place: Social representations and development in Nepal. Comparative Studies in Society and History, 34(3), 491-513.

Pinkney, A.M. (2013). An ever-present history in the land of the gods: Modern Māhātmya writing on Uttarakhand. International Journal of Hindu Studies, 17(3), 229-260.

Rangan, H. (1996). From Chipko to Uttaranchal: Development, environment, and social protest in the Garhwal Himalayas, India. In R. Peet and M. Watts (Eds), Liberation ecologies: Environment, development, social movements (pp. 205-226). London and New York: Routledge.

---. (2000). Of myths and movements: Rewriting Chipko into Himalayan history. New York and London: Verso.

Rawat, A.S. (1999). Forest management in Kumaon Himalaya: Struggle of the marginalised people. New Delhi: Indus Pub. Co.

Sharma, M. (2009). Passages from nature to nationalism: Sunderlal Bahuguna and Tehri Dam opposition in Garhwal. Economic and Political Weekly, 44(8), 35-42.

Shiva, V., \& Bandyopadhyay, J. (1986). The evolution, structure, and impact of the Chipko movement. Mountain Research and Development, 6(2), 133-142.

Sivaramakrishnan, K., \& Agrawal, A. (2003). Regional modernities in stories and practices of development. In K. Sivaramakrishnan and A. Agrawal (Eds), Regional modernities: The cultural politics of development in India (pp. 1-61). Stanford: Stanford University Press.

Tillin, L. (2013). Remapping India: New states and their political origins. London: C. Hurst \& Co.

Urry, J. (2003). Social networks, travel and talk. The British Journal of Sociology, 54(2), $155^{-175 .}$

Verstappen, S. (2016). Mobility and the region: A multi-scalar ethnography of the Vohra Gujarati community, in India and abroad ( $\mathrm{PhD}$ dissertation). University of Amsterdam.

Whitmore, L. (2012). The challenges of representing Shiva: Image, place, and divine form in the Himalayan Hindu shrine of Kedarnath. Material Religion, 8(2), 215-241.

Yugwani (1977, June 5). Uttarakhand Sangharsh Vahini kā Gat $\square$ han [The making of the Uttarakhand Sangharsh Vahini]. Yugwani archives, Dehradun. 